\title{
Importance of anticomplement immunofluorescence antibody titration for diagnosing varicella-zoster virus infection in Bell's palsy
}

\author{
S SHIGETA,* M BABA,* M OGATA, $\dagger$ H NOZAKI, $\ddagger$ A OKUAKI, $\ddagger$ S NAKAMURA
}

From the *Department of Bacteriology, $\dagger$ Central Clinical Laboratories, the $\ddagger$ Department of Anaesthesiology, Fukushima Medical College, Fukushima, and the §Division of Clinical Neurology, Institute of Brain Diseases, Tohoku University School of Medicine, Sendai, Japan

SUMMARY Anticomplement Immunofluorescence was used for antibody titration against varicellazoster virus (VZV) in 43 patients with peripheral facial palsy. Nine of 31 patients $(29 \%)$ with Bell's palsy and eight of 12 patients $(75 \%)$ with Ramsey-Hunt syndrome had anticomplement immunofluorescence antibody titres of $\geqslant 1 / 10$. On the other hand, none of 14 patients with herpes simplex virus (HSV) infection and 51 healthy adults showed anticomplement immunofluorescence antibody titres of $\geqslant 1 / 10$. The anticomplement immunofluorescence antibody titre in two patients with Ramsey-Hunt syndrome increased later and decreased sooner than the indirect immunofluorescence antibody titre, becoming undetectable at 66 and 104 days, respectively, after onset of the disease. There was no cross reaction between anti-VZV and anti-HSV antibodies in the patients who showed a positive antibody rise for VZV. As the acute stage of VZV infection is obscure in the patients with peripheral facial palsy without herpes the screening of anticomplement immunofluorescence antibody to VZV at titres $\geqslant 1 / 10$ may be useful for the diagnosis of VZV infection in patients with peripheral facial palsy.

The direct cause of Bell's palsy (idiopathic peripheral facial palsy) is unknown. Some part of the disease, however, is considered to be caused by varicellazoster virus (VZV) infection. ${ }^{1-6}$ As there is no evidence of herpetic eruption, isolation of VZV from patients with Bell's palsy is very difficult. Although serum antibody titration for VZV is useful for virological diagnosis, it is necessary to obtain proper paired (acute and convalescent) sera from the patients to detect any clinically important rise in antibody.

In a previous paper we reported that VZV anticomplement immunofluorescence using paired sera from patients with varicella or herpes zoster showed a specific response between the acute and convalescent stages of the diseases. ${ }^{7}$ We observed, however, that the sensitivity of anticomplement immunofluorescence was somewhat less than membrane immunofluorescence and indirect immunofluorescence. ${ }^{7}$ In that study we also titrated VZV antibody using anticomplement immunofluorescence in healthy adults and found that their antibody titre was always less than $1 / 10$. Thus we concluded that among the population aged more than 20 years people who Accepted for publication 29 May 1986 had anticomplement immunofluorescence antibody for VZV with a titre $\geqslant 1 / 10$ had probably had a recent VZV infection. In the present paper we report the incidence of anticomplement immunofluorescence antibody in the patients with peripheral facial palsy and matched controls.

\section{Material and methods}

VIRUS STRAIN AND TISSUE CULTURE

The Hirai strain of VZV, which was isolated from a patient with herpes zoster was routinely used in the experiment. The details of propagation of this strain in tissue culture cells have been reported previously. ${ }^{7}$

The Kos strain of herpes simplex virus (HSV) type 1 was used for the preparation of anticomplement immunofluorescence antigen. A human embryo fibroblast strain was subcultured with Eagle's minimal essential medium containing $10 \%$ new born calf serum, $100 \mu \mathrm{g} / \mathrm{ml}$ of streptomycin, and 100 units $/ \mathrm{ml}$ of penicillin. For the virus infection the medium was changed to minimal essential medium containing $2 \%$ fetal calf serum and the same antibiotics. 
PATIENT SELECTION

Thirty one patients with Bell's palsy and 12 patients with the Ramsey-Hunt syndrome who visited the outpatient clinic of the department of anaesthesiology of Fukushima Medical College hospital were included in the study. The patients with Bell's palsy were aged from 26 to 76 years (average 51.2 years) and comprised 16 men and 15 women. The patients with Ramsey-Hunt syndrome were aged from 27 to 74 years (average 51.3 years) and included nine men and three women.

\section{SERUM SAM PLES}

The blood samples for virus serology were obtained from all patients with peripheral facial palsy on the first visit, and the second or third samples were taken one to 50 weeks later from 14 patients with Bell's palsy and five patients with Ramsey-Hunt syndrome. Single blood samples were taken from 14 patients with HSV infection and 51 healthy adults for use as controls. The healthy controls were aged between 21 and 79 years (average 40.8 ) and included 28 men and 23 women. Of 14 convalescent serum samples from patients with HSV infection, 10 were from patients with HSV stomatitis, or HSV cold sores, or both, and four were from patients with HSV encephalitis. All HSV serum samples were collected at the Institute of Brain Diseases, Tohoku University School of Medicine between 15 and 40 days after onset of illness. All serum samples were inactivated at $56^{\circ} \mathrm{C}$ for 30 minutes before use.

\section{PROCEDURE FOR ANTICOMPLEMENT \\ IMMUNOFLUORESCENCE}

The procedure used for anticomplement immunofluorescence antibody titration for VZV has been described previously. ${ }^{7}$ Briefly, human embryo fibroblast monolayers, which had been grown on a glass slide $(25 \times 7.5 \mathrm{~cm})$, infected with VZV, and which showed cytopathic effect in $80 \%$ of the sheet after 48 hours of infection, were prepared. The infected monolayer cells were washed twice with phosphate buffered saline (PBS, pH 7.2), air dried and fixed with acetone for 10 minutes at room temperature. The fixed cell monolayer was cut into 32 small squares $(5 \times 5 \mathrm{~mm})$ with nail polish. Serial twofold dilutions of serum in veronal buffered saline containing 4 units of guinea pig complement (GP-C', Kyokuto Pharmaceutical Co Ltd, Tokyo) were added to the sectioned monolayer on the slide. We obtained an optimum concentration of GP-C' for anticomplement immunofluorescence using a chessboard titration with a convalescent herpes zoster serum. The optimum concentration of GP-C' was 4 to 8 units. The slides with applied serum were incubated at $37^{\circ} \mathrm{C}$ for 30 minutes in a humidified chamber and then washed twice with PBS. After being washed the slides were stained with an optimum dilution of goat antiserum against guinea pig $\mathrm{C}_{3}$ labelled with fluorescein isothiocyanate (FITC, Medical and Biological Laboratories Ltd, Tokyo) at $37^{\circ} \mathrm{C}$ for 30 minutes. The stained slides were washed twice with PBS, mounted in $20 \%$ glycerol in phosphate buffered saline, and then observed for fluorescence using a transmitted light fluorescence microscope (Nikon, Tokyo Japan; mercury arc lamp, Toshiba SH-100).

Indirect immunofluorescence was carried out on the same preparations of VZV antigen used in anticomplement immunofluorescence and we titrated the patient's antibody with rabbit antihuman IgG conjugated with FITC (Fujizoki Pharmaceutical Co, Tokyo). The glass slides with VZV antigen were reacted with dilutions of the patients' serum and fluorescent antiglobulin each for 30 minutes at $37^{\circ} \mathrm{C}$ with five minute intermittent washings in PBS.

Table 1 Anti-VZV anticomplement immunofuorescence antibody titre in patients with peripheral facial palsy, herpes simplex virus infections, and in healthy controls

\begin{tabular}{|c|c|c|c|c|c|c|c|}
\hline \multirow[b]{2}{*}{ Clinical diagnosis } & \multirow[b]{2}{*}{ No of patients tested } & \multicolumn{5}{|c|}{ No of patients with titre of } & \multirow[b]{2}{*}{ Positive per cent } \\
\hline & & $<10$ & 10 & 20 & 40 & 80 & \\
\hline $\begin{array}{l}\text { Bell's palsy ( } 26-76 \text { years) } \\
\text { Ramsey-Hunt syndrome ( } 27-74 \text { years) }\end{array}$ & $\begin{array}{l}31 \\
12\end{array}$ & $\begin{array}{r}22 \\
3\end{array}$ & 4 & $\begin{array}{l}2 \\
2\end{array}$ & $\begin{array}{l}2 \\
5\end{array}$ & $\begin{array}{l}1 \\
2\end{array}$ & $\begin{array}{r}29 \cdot 0 \\
75 \cdot 0\end{array}$ \\
\hline $\begin{array}{l}\text { Herpes simplex stomatitis } \uparrow \text { or } \\
\text { labialis ( } 24-69 \text { years) }\end{array}$ & 10 & 10 & & & & & 0.0 \\
\hline $\begin{array}{l}\text { Herpes simplex } \ddagger \text { encephalitis } \\
\quad(31-50 \text { years) } \\
\text { Healthy controls ( } 21-57 \text { years) } \\
\text { Health controls ( } 69-79 \text { years) }\end{array}$ & $\begin{array}{r}4 \\
41 \\
10\end{array}$ & $\begin{array}{r}4 \\
41 \\
10\end{array}$ & & & & & $\begin{array}{l}0.0 \\
0.0 \\
0.0\end{array}$ \\
\hline
\end{tabular}

*For most of the patients single serum was tested. When paired or plural sera were tested for one patient the highest antibody titre was described.

†Herpes simplex virus was isolated from all of the patients. Anti-HSV anticomplement immunofluorescence antibody titre in patients ranged from $1 / 10$ to $1 / 40$.

†Convalescent sera of patients with HSV encephalitis. Anti-HSV antibody titres ranged from 1/40 to 1/160. 


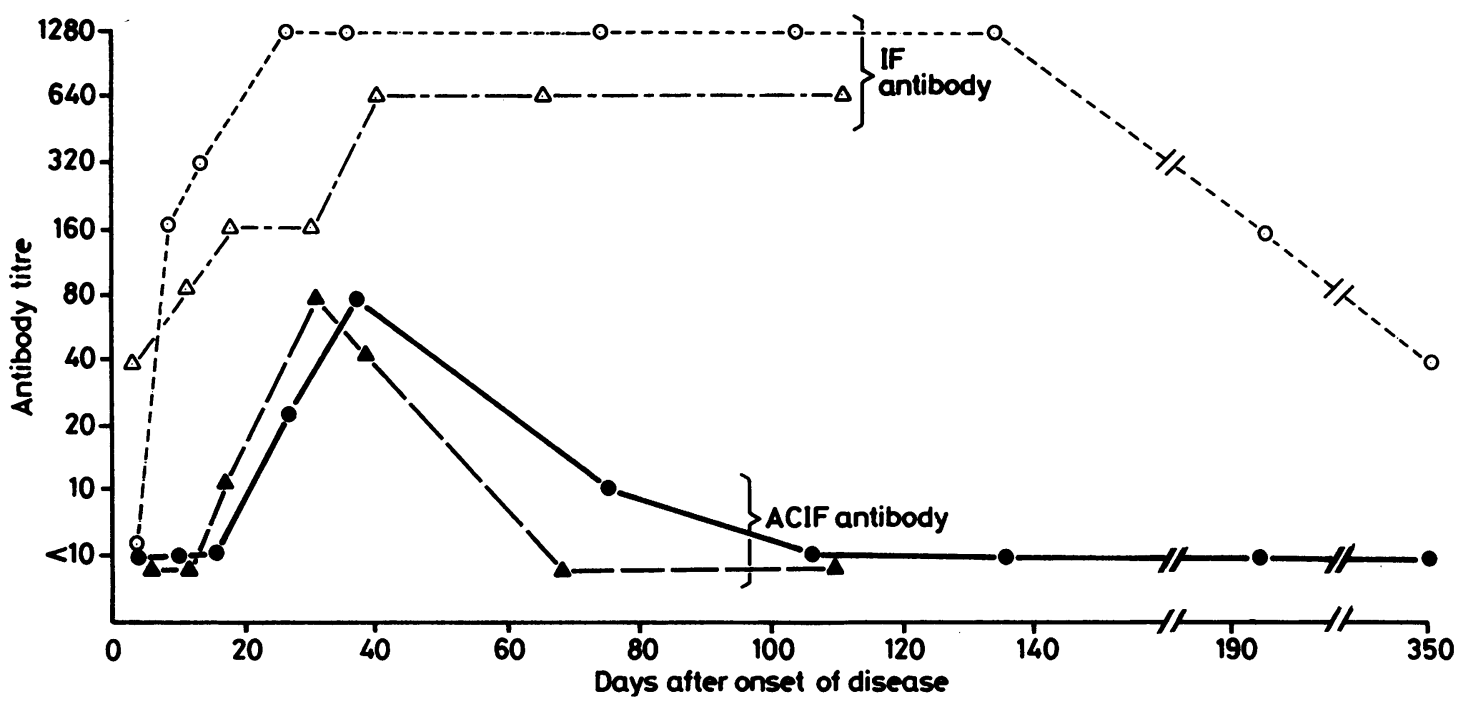

Anti-VZV antibodies of patients with Ramsey-Hunt syndrome. Human embryo fibroblast monolayers infected with VZV were fixed with acetone and stained with acute and convalescent sera of two patients using both indirect immunofluorescence and anticomplement immunofluorescence methods.

$\mathrm{O}-\mathrm{O}, \boldsymbol{O}=$ Patient $\mathrm{A} ; \Delta-\Delta, \boldsymbol{\Delta}-\mathbf{\Delta}=$ patient $\mathrm{B} ; \mathrm{O}-\mathrm{O}, \Delta-\Delta=$ indirect immunofluorescence antibody; $-\boldsymbol{\Lambda}, \boldsymbol{\Delta}-\boldsymbol{\Delta}=$ anticomplement immunofluorescence antibody.

\section{Results}

\section{TITRATION OF ANTICOMPLEMENT}

\section{IMMUNOFLUORESCENCE ANTIBODY OF}

PATIENTS WITH PERIPHERAL FACIAL PALSY

All serum samples were titrated for VZV antibody using both anticomplement immunofluorescence and indirect immunofluorescence methods. Table 1 shows that nine of 31 patients with Bell's palsy $(29 \%)$ had anticomplement immunofluorescence antibody with titres of $1 / 10$ to $1 / 80$. Nine of 12 patients with Ramsey-Hunt disease $(75 \%)$ had anticomplement immunofluorescence antibody titres between 1/20 and $1 / 80$. On the other hand, 14 patients with HSV infections and 51 healthy adults between 27 and 79 years of age, did not have anticomplement immunofluorescence antibody titres of $\geqslant 1 / 10$. All patients and the healthy adults tested had indirect immunofluorescence antibody titres of more than 1/10 (data not shown). The low incidence of de- tectable anticomplement immunofluorescence antibody in healthy adults may be due to the rapid decrease of anticomplement immunofluorescence antibody after VZV infection. The figure shows the increase and decrease in antibody titres in patients with Ramsey-Hunt disease. Anticomplement immunofluorescence antibody titres decreased to less than $1 / 10$ at 104 days after the onset of the disease in patient $A$, and at 66 days after onset in patient $B$. On the other hand, indirect immunofluorescence antibody increased more rapidly than anticomplement immunofluorescence antibody in both patients and the titres remained high at 1/1280 and 1/640, respectively, for more than 135 and 110 days. In patient $\mathbf{A}$, in whom indirect immunofluoresence antibody titres were followed up for a longer time, the antibody had decreased to $1 / 160$ (one eighth of the maximum titre) by 195 days and to $1 / 40$ by 350 days after onset of the disease (figure). Table 2 shows the results of VZV antibody titrations of 18 paired sera

Table 2 Antibody rise against VZV in patients with peripheral facial palsy

\begin{tabular}{llll}
\hline & & No of antibody rise: & \\
\cline { 3 - 4 } Disease & No of paired serum & $\begin{array}{l}\text { With anticomplement } \\
\text { immunofluorescence }\end{array}$ & With indirect immunofluorescence \\
\hline Bell's palsy & 14 & 5 & 3 \\
Ramsey-Hunt syndrome & $4^{*}$ & 4 & 4 \\
\hline
\end{tabular}

"One patient from whom inadequate paired sera were obtained was excluded. 
Table 3 Anticomplement immunofluorescence antibody titre of patients against VZV and HSV antigens

\begin{tabular}{lccc}
\hline Disease & Day of infection & Anti-VZV & Anti-HSV \\
\hline Ramsey Hunt syndrome & 1 & $<10$ & $<10$ \\
Ramsey Hunt syndrome & 25 & 80 & $<10$ \\
Ramsey Hunt syndrome & 7 & $<10$ & $<10$ \\
Ramsey Hunt syndrome & 28 & 40 & $<10$ \\
Herpes zoster & 31 & $<10$ & $<10$ \\
Herpes zoster & 29 & 40 & $<10$ \\
Peripheral facial palsy & 6 & 80 & $<10$ \\
Peripheral facial palsy & 28 & 20 & $<10$ \\
& 6 & 640 & $<10$ \\
& 12 & 160 & $<10$ \\
\end{tabular}

${ }^{*} \mathrm{ND}=$ Not defined.

from patients with peripheral facial palsy, using both anticomplement immunofluorescence and immunofluorescence methods. Of the 14 patients with Bell's palsy, five showed appreciable increases in titres of anticomplement immunofluorescence antibody and three patients showed an increase in indirect immunofluorescence antibody, while four patients with Ramsey-Hunt syndrome all showed an appreciable increase in both the anticomplement immunofluorescence and indirect immunofluorescence antibody titres.

\section{TITRATION OF ANTICOMPLEMENT}

\section{IMMUNOFLUORESCENCE ANTIBODY OF PAIRED}

SERA FOR BOTH VZV AND HSV

To show any cross reactions between anti-HSV antibody and VZV antigen or anti-VZV antibody and HSV antigen paired sera from eight patients with VZV infection were examined for both anti-VZV and anti-HSV antibodies using anticomplement immunofluorescence. Table 3 shows that none of the paired sera showed a rise in antibody titre against HSV, although all of them showed an appreciable rise in antibody against VZV. Moreover, none of the eight sera, which possessed anticomplement immunofluorescence antibody for VZV of titres between $1 / 10$ and $1 / 160$, possessed antibody to HSV at a titre of more than $1 / 10$. Only one serum, with an anti-VZV antibody of $1 / 640$, had an anti-HSV antibody of $1 / 10$.

\section{Discussion}

In the previous paper we reported a lower incidence of anticomplement immunofluorescence antibody than membrane immunofluorescence antibody in a population of healthy subjects. ${ }^{7}$ It was especially remarkable that the anticomplement immunofluorescence antibody titre was less than $1 / 10$ in all 22 healthy adults. In this study we also tested 51 healthy adults for antibody detected by anticomplement immunofluorescence and confirmed that anticomplement immunofluorescence antibody was not detected at titres of $\geqslant 1 / 10$. Reports of the anticomplement immunofluorescence test for VZV by other workers indicate that it gave comparable sensitivity results with the membrane immunofluorescence test, ${ }^{89}$ and $99 \%$ of adult blood donors possessed anticomplement immunofluorescence antibody. ${ }^{9} \mathrm{Al}$ though these workers took the lowest titre for detectable anticomplement immunofluorescence antibody (1/5), while our minimum positive titre was $1 / 10$, there is still some discrepancy between their results and ours. Their titration method had two steps, the first being incubation of antigen with antiserum and the second incubation with complement. By comparison, our method is one step-that is, simultaneous incubation of antigen, antibody, and complement. One of the authors commenting on our data suggested that low antibody titres may have been due to the anticomplementary effect of serum during the incubation. ${ }^{8}$ We tested all sera, however, for anticomplementary activity using a hemolysin and sheep erythrocyte system, and no anticomplementary activity was observed. We also determined an optimum dilution of GP-C' for the anticomplement immunofluorescence using a chessboard titration of GP-C' against antiserium. As previously reported our anticomplement immunofluorescence method is less sensitive than membrane immunofluorescence or indirect immunofluorescence, but this insensitivity gives a negative incidence of anticomplement immunofluorescence antibody in a healthy adult population and also facilitates a diagnosis of VZV infection in adults with Bell's palsy. We also reported in the previous paper that anticomplement immunofluorescence antibody rose in patients with VZV infections but that no heterotypic reactions to HSV and human cytomegalovirus antigens were observed 
in those patients. ${ }^{7}$ We have confirmed these observations in the present study and also that no anticomplement immunofluorescence antibody for VZV was detected in patients with HSV infections (HSV stomatitis, herpes labialis, HSV encephalitis), and that no anticomplement immunofluorescence antibody rise to HSV was observed in paired sera from patients with VZV infection. In particular, six patients with peripheral facial palsy who showed an antibody rise to VZV did not respond to HSV at all. Our results may not necessarily eliminate the possibility of HSV infection as a cause of Bell's palsy. The negative incidence of anticomplement immunofluorescence antibody for VZV in the control group and positive incidence in $29 \%$ of the adult patients with Bell's palsy, however, indicated that these patients had had a VZV infection within 60 to 100 days before the serum specimen was taken (figure). The incidence of VZV infection in Bell's palsy is similar to the results obtained by Tomita et al, in which they titrated complement fixing antibody for VZV in paired sera and $(25 \%)$ of 44 cases showed increased antibody titre. ${ }^{3} \mathrm{~A}$ lower incidence of VZV infection in Bell's palsy, however, was reported by other workers, and nine of 133 cases $(6.8 \%),{ }^{5}$ three of 33 cases $(9 \cdot 1 \%),{ }^{2}$ nine of 84 cases $(10 \cdot 7 \%)^{4}$ of Bell's palsy were diagnosed virologically as VZV infections. Uncertainty over the time of the acute stage of VZV infection in the patients with peripheral facial palsy without cutaneous herpes may show as a lower incidence of antibody rise using the indirect immunofluorescence method in which antibody titre increases promptly after infection. Anticomplement immunofluorescence antibody titration for VZV antibody in paired sera from patients with Bell's palsy was also as likely as with the indirect immuno- fluorescence method to give positive results if the acute sera were taken early. ${ }^{46}$

Anticomplement immunofluorescence titration for VZV antibody using single or multiple sera from patients with Bell's palsy and setting a titre of positivity at $1 / 10$ is a useful tool for diagnosing VZV infection in this aetiologically obscure disease.

\section{References}

1 Aitken RS, Brain RT. Facial palsy and infection with zoster virus. Lancet 1933;i:19-22.

2 Berg R, Forsgren M, Schiratzki H. Acute facial palsy: some clinical and virological observations. Acta Otolaryngol 1976;81: 462-7.

3 Tomita H, Hayakawa W, Hondo R. Varicella-zoster virus in idiopathic facial palsy. Arch Otolaryngol 1972;95:364-8.

4 Mertens T, Thomas JP, Zippel C, Eggers HJ. Peripheral facial palsy and viral infections. Findings and problems. Med Microbiol Immunol 1982;171:77-83.

5 Mair IWS, Flugsrud LB. Peripheral facial palsy and herpes zoster infection. J Laryngol Otol 1976;90:373-9.

6 Peitersen E, Caunt AE. The incidence of herpes zoster antibodies in patients with peripheral facial palsy. $J$ Laryngol Otol 1970;84:65-70.

7 Shigeta S, Baba M, Ogata M, Iizima S, Murai C. Anticomplement Immunofluorescence for the titration of antibody to varicella-zoster virus. Microbiol Immunol 1981;25:295-303.

8 Gallo D, Schmidt NJ. Comparison of anticomplemen immunofluorescence and fluorescent antibody to membrane antigen tests for determination of immunity status to varicellazoster virus and for serodifferentiation of varicella-zoster and herpes simplex virus infections. $J$ Clin Microbio/ 1981;14:539-43.

9 Preissner CM, Steinberg SP, Gershon AA, Smith TF. Evaluation of the anticomplement immunofluorescence test for detection : of antibody to varicella-zoster virus. J Clin Microbio 1982;16:373-6.

Requests for reprints to: Dr S Shigeta, Department of Bacteriology, Fukushima Medical College, Fukushima 960, Japan. 